\title{
Balanced Scorecard at the Royal Library, Copenhagen
}

\author{
by KARL KRARUP
}

\section{INTRODUCTION}

This is a short description of how the Royal Library has taken a balanced scorecard into use as a strategic management tool for creating a better connection between our strategic goals and our day-to-day activities.

Balanced scorecard is used as an instrument

- to represent strategic goals in such a way that our actual performance can be measured in relation to these goals;

- to negotiate the goals and performance of the departments in such a way that the heads of department keep a fair level of autonomy in running their departments, while at the same time giving the head of the institution a good overview of the actual performance;

- to make the individual departments' contributions to the institutional performance explicit to personnel and leaders;

- $\quad$ to identify and monitor important strategic areas of development as a part of steering it;

- $\quad$ to make the library and its performance more transparent to all interested actors.

\section{THE ROYAL LIBRARY}

The Royal Library is the National Library of Denmark and the University Library for Copenhagen University. It is also a research institution, and a culture and museum institution. The Royal Library exists since 1648, as University Library since 1927 with fore-bears back to 1482 . It is an institution with direct reference to The Ministry of Culture. Its size in personnel and economics can be seen from diagram 1 stating its annual appropriation for $2001-2005$ in fixed prices and the number of full-time equivalents of staff. 
Diagram 1: $\quad$ Annual appropriation $2001-2005$ - fixed prices and number of staff in fulltime equivalents

\begin{tabular}{|c|c|c|c|c|c|}
\hline Fixed prices & $\mathbf{2 0 0 1}$ & $\mathbf{2 0 0 2}$ & $\mathbf{2 0 0 3}$ & $\mathbf{2 0 0 4}$ & $\mathbf{2 0 0 5}$ \\
\hline $\begin{array}{c}\text { Net appropriation in } \\
\text { mil. DKK }\end{array}$ & 164 & 163 & 162 & 158 & 154 \\
\hline Fulltime equivalents & 300 & 297 & 275 & 265 & 258 \\
\hline
\end{tabular}

As can be seen the annual appropriation is getting smaller year by year, and staff is being diminished accordingly. At the same time the Government is asking the library to perform better and more efficiently. This is not a new situation; you could say that the Danish Government has the overall strategy of asking its institutions to produce more for less.

From diagram 2 it can be seen that the Royal Library has a classical hierarchical structure with a director general, 3 area directors and a number of departments. One of the main principles of the organisation is called "structured decentralisation", indicating that the frames and the goals are set in a top-down way, but at the same time the heads of department and the staff within these frames can show initiative and have a certain amount of freedom in their work to achieve the goals set for the departments. 
Diagram 2: $\quad$ The Royal Library - Organisation 2003

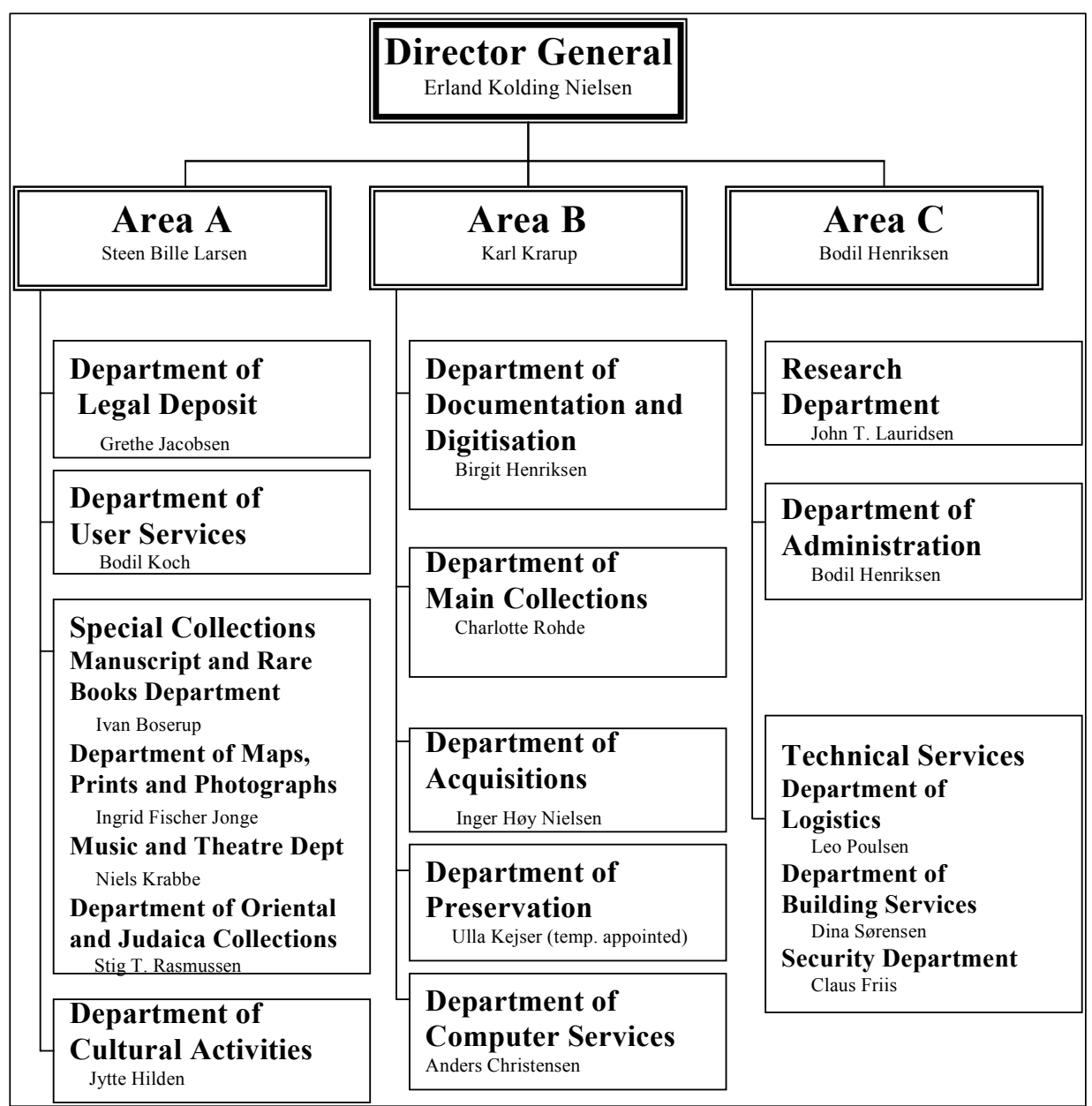

\section{THE CONTEXT FOR MANAGEMENT OF PUBLIC INSTITUTIONS IN DENMARK}

The paradigm of steering is the paradigm of management of public institutions, and this paradigm is implemented in a number of ways. In our Annual Accounts to the Ministry we state the result of the year in relation to the goals set for the year, and set out our goals for the next year. We have a multi-annual contract agreement with the Ministry on 
main goals, and of course we also send out our Annual Report, the library's own presentation of the Royal Library's situation, efforts and results during the year.

A special sort of steering is determined for the Royal Library's university function by the budget model. The budget model is allocating the resources for the University Library function in a mathematical way. The amount of resources available is calculated from the number of students and study grants, the number of researches and research grants, and the number of lending in the year. This does not mean though that the amount of resources available for the library will be increased in proportion to an increase in lending. The budget model is a distribution model for one collective grant for a number of institutions.

As can be seen the steering paradigm is very important in the public sector and has an almost algorithmic character. This is spelled out in diagram 3.

Diagram 3: $\quad$ The steering paradigm

\section{$\mathbf{R}=\mathbf{P}-\mathbf{G}$}

Result $=$ Product - Goal for product

\section{$\mathbf{P}=\mathbf{F}(\mathbf{A R}, \mathbf{O})$}

Product $=$ Function (annual resources, organisation)

The first line states that the results are determined by the relationship between the product and the goal for the products, which means that the result is plus or minus depending on the product being larger or smaller than the goal set for the products. One has to have goals to know if the products are satisfying.

The second line states that the products are a function of the annual resources and the organisation of these resources. As the amount of resources available for the institution is diminishing, it puts quite a pressure on your ability to organise. 


\section{THE BALANCED SCORECARD}

The balanced scorecard is an instrument, which fits very well into the steering paradigm. It is an instrument for creating managerial coherence between the institution's visions and strategic aims and the institution's day-to-day management and performance.

The basic concept of the balanced scorecard and its implementation can be expressed in a few steps. To make our strategy operational in observable terms, we have to take the following steps:

- $\quad$ Setting up the strategic goals, i.e. stating which are the goals.

- Establish the critical success factors, i.e. how we express our goals.

- Establish the critical performance indicators, i.e. how we measure the values we expressed in the critical success factors

A balanced scorecard being a balanced approach means that we set up strategic goals, critical success factors and critical performance indicators for a number of perspectives on the institution. We have chosen four perspectives:

- the internal perspectives relating to our internal production process,

- the user perspectives relating to the users use of the library,

- a developmental perspective related to the development of our production process and institutional arrangements, and

- the economic perspectives relating to the costs of running the library.

We have taken the balanced scorecard in use for the whole library, and we have gone through a number of developmental stages:

2000 - 2001: the director and the area directors set out the strategic goals, and the area directors went into a dialogue with the heads of department creating a bottom-up procedure and operationalisation in the departments: where and how does this department contribute to these strategic goals of the library? We started with using spreadsheets and went on to use professional software for the implementation of balanced scorecards. It is important that professional software is used because otherwise the logic, rules and displays of balanced scorecard will not be applied sufficiently. Coupling the departmental level with the institutional level was a focus area. For example the lending of the whole library is composed of the lending from the individual parts of the library. It can be a complex task. We set up reporting procedures, and this is an area where an institution has to invest quite an effort, because we wanted each department to be able to follow its own indicators and report on these to the common system. It requires training, understanding and discipline. It was decided that all 
performance indicators should be reported on our internal web, so every person at the library was able to follow every departments archival goal and performance.

In 2002 the balanced scorecard set-up of critical success factors and critical performance indicators were revised to establish a better connection between institutional level and departmental level. We also had an important discussion about the use of total statistics running on balanced scorecard versus the use of indicators only. A central focus area for 2002 was the Royal Library as a hybrid library, and we used the indicators of the balanced scorecard to express our goal of making the Royal Library more digital in such a way that we could measure the amount of development in making it more digital.

The next step in 2003 was to simplify our set-up of critical success factors and critical performance indicators, i.e. we decided to focus on fewer success factors and indicators and chose to use indicators instead of full statistics for an area to a greater extent. But as the Royal Library is an institution with four main function areas, it is not easy to monitor it with a balanced scorecard.

We used professional consultants in implementing a balanced scorecard for the Royal Library, and they fulfilled an important function in spelling out our vision, our strategic goal and translating these into critical success factors and indicators, and in implementing this in operational form. Two of the area directors and two academic members of staff from the Administration ran the practical implementation. These four persons still constitute the basic organisation of implementing and running the balanced scorecard. In 2003 we have had the pleasure of being used as a showcase for an institution embarking on the balanced scorecard method. 


\section{THE ROYAL LIBRARY IN BALANCED SCORECARD TERMS}

In the following I will show how we transformed our vision through strategic goals to relevant performance indicators through a number of steps. The vision is spelled out in diagram 4.

\section{Diagram 4: $\quad$ The Royal Library's vision}

To be a national driving force in the development of Denmark, a society of culture and knowledge and give the users relevant, quick and easy access to information and cultural heritage.

To be the central library for the University of Copenhagen supporting research and education within its subject areas.

To provide the leading basis in the world for documentation about Denmark and Danish conditions in close cooperation with relevant institutions in the country.

To continue to preserve the cultural heritage of the past, to gather together the cultural values of the present and thus give the citizens of the future the chance to study and explore their own selves as seen in the light of the past and the present.

The vision is spelled out in ten strategic goals as shown in diagram 5 .

\section{Diagram 5: $\quad \underline{\text { Ten strategic goals }}$}

\begin{tabular}{|l|l|l|}
\hline $\begin{array}{l}\text { The collections } \\
\text { The Royal Library must } \\
\text { continue to extend all } \\
\text { collections as well as } \\
\text { access to information in } \\
\text { digital form both } \\
\text { nationally and } \\
\text { internationally. }\end{array}$ & $\begin{array}{l}\text { National Library } \\
\text { As national library the Royal } \\
\text { comprary must collect the most } \\
\text { within its particular areas, } \\
\text { make these avail-able to the } \\
\text { present and make a special } \\
\text { effort to preserve this part of } \\
\text { the cultural heritage for } \\
\text { posterity, including the digital } \\
\text { cultural heritage }\end{array}$ & $\begin{array}{l}\text { Synergy effects } \\
\text { The Royal Library must } \\
\text { conduct its main functions: } \\
\text { national library, university } \\
\text { library, research institution } \\
\text { and cultural institution so that } \\
\text { they support and develop each } \\
\text { other and together create } \\
\text { results for the institution's } \\
\text { target groups within each area } \\
\text { which surpass what each of } \\
\text { the four could manage on its } \\
\text { own. }\end{array}$ \\
\hline $\begin{array}{l}\text { The information } \\
\text { technological } \\
\text { development } \\
\begin{array}{l}\text { The Royal Library must } \\
\text { facilitate the user's }\end{array}\end{array}$ & $\begin{array}{l}\text { Museum and Cultural } \\
\text { Institution } \\
\text { As museum and cultural } \\
\text { institution the Royal Library } \\
\text { must in its mediation reflect }\end{array}$ & $\begin{array}{l}\text { The running of the library } \\
\text { The Royal Library must be a } \\
\text { well-run business and run in } \\
\text { such a way that there will be } \\
\text { resources for continued }\end{array}$ \\
\hline
\end{tabular}




\begin{tabular}{|l|l|l|}
\hline $\begin{array}{l}\text { access to the collections } \\
\text { and further the } \\
\text { exploitation of the } \\
\text { potentials of the } \\
\text { collections through } \\
\text { continuous intensive } \\
\text { exploitation of the } \\
\text { information technology } \\
\text { possibilities. }\end{array}$ & $\begin{array}{l}\text { its purposes, tasks and frames, } \\
\text { giving the Danish population } \\
\text { the chance to understand and } \\
\text { in a relevant way experience } \\
\text { its common cultural heritage, } \\
\text { history and present age. }\end{array}$ & $\begin{array}{l}\text { development of the } \\
\text { institution. }\end{array}$ \\
\hline \multirow{1}{*}{$\begin{array}{l}\text { Research Institution } \\
\text { As research institution the } \\
\text { Royal Library must conduct } \\
\text { research, which supports and } \\
\text { develops its tasks, and } \\
\text { increase its research activities } \\
\text { until this corresponds with } \\
\text { that of the other national } \\
\text { cultural institutions. }\end{array}$} & \\
\hline
\end{tabular}

These ten strategic goals were again expressed in a set of critical success factors within the four perspectives as can be seen in diagram 6 for the year 2002. As was stated earlier we have simplified the set-up of critical success factors for 2003 , as can be seen from the diagram 7. It is the same four perspectives and it is the same ten strategic goals, but we have simplified the structure here.

For each of these critical success factors we have a number of critical performance indicators for one or more departments. 
Diagram 6: $\quad$ Critical Success factors 2002

\begin{tabular}{|c|c|c|c|}
\hline A: Internal & $\begin{array}{l}\text { B: User/outside } \\
\text { world }\end{array}$ & C: Development & $\begin{array}{l}\text { D: Economy/ } \\
\text { running of library }\end{array}$ \\
\hline $\begin{array}{l}\text { Building up } \\
\text { conventional } \\
\text { collections in UL } \\
\text { (University } \\
\text { Library) }\end{array}$ & $\begin{array}{l}\text { Usage of library: } \\
\text { conventional loans }\end{array}$ & $\begin{array}{l}\text { Staff-political } \\
\text { development targets }\end{array}$ & Increased income \\
\hline $\begin{array}{l}\text { Building up digital } \\
\text { collections in UL }\end{array}$ & $\begin{array}{l}\text { Usage of library: } \\
\text { requests for } \\
\text { guidance }\end{array}$ & $\begin{array}{l}\text { Catalogues in e- } \\
\text { form/ retro } \\
\text { conversion }\end{array}$ & $\begin{array}{l}\text { Improved efficiency } \\
\text { of the running of } \\
\text { the library }\end{array}$ \\
\hline $\begin{array}{l}\text { Quality targets for } \\
\text { collection building } \\
\text { in UL }\end{array}$ & $\begin{array}{l}\text { Usage of library: } \\
\text { guest in reading } \\
\text { rooms and centres }\end{array}$ & $\begin{array}{l}\text { Digitisation of } \\
\text { national works }\end{array}$ & $\begin{array}{l}\text { Release of } \\
\text { resources }\end{array}$ \\
\hline $\begin{array}{l}\text { Building up } \\
\text { conventional } \\
\text { collections in NL } \\
\text { (National Library) } \\
\text { - not legal deposit } \\
\end{array}$ & $\begin{array}{l}\text { Usage of library: } \\
\text { visits at service } \\
\text { points }\end{array}$ & Research & $\begin{array}{l}\text { Exploitation of new } \\
\text { salary system }\end{array}$ \\
\hline $\begin{array}{l}\text { Building up } \\
\text { conventional } \\
\text { collections in NL, } \\
\text { legal deposit }\end{array}$ & $\begin{array}{l}\text { Usage of library: } \\
\text { electronic document } \\
\text { delivery }\end{array}$ & E-services & $\begin{array}{l}\text { Up-to-date } \\
\text { management } \\
\text { information }\end{array}$ \\
\hline $\begin{array}{l}\text { Building up digital } \\
\text { collections in NL }\end{array}$ & $\begin{array}{l}\text { Usage of e- } \\
\text { mediation (web } \\
\text { visits) }\end{array}$ & $\begin{array}{l}\text { RL's position in } \\
\text { larger national and } \\
\text { international } \\
\text { networks }\end{array}$ & $\begin{array}{l}\text { Exploitation of } \\
\text { quota scheme }\end{array}$ \\
\hline $\begin{array}{l}\text { Quality targets for } \\
\text { collection building } \\
\text { in NL }\end{array}$ & $\begin{array}{l}\text { Quality targets for } \\
\text { library services }\end{array}$ & $\begin{array}{l}\text { Total plan for retro- } \\
\text { conversion }\end{array}$ & $\begin{array}{l}\text { Optimisation of e- } \\
\text { contract }\end{array}$ \\
\hline $\begin{array}{l}\text { Collection } \\
\text { preservation }\end{array}$ & $\begin{array}{l}\text { Usage of cultural } \\
\text { offers: visits to } \\
\text { exhibitions and } \\
\text { guests at events }\end{array}$ & $\begin{array}{l}\text { IT-development } \\
\text { projects }\end{array}$ & $\begin{array}{l}\text { Maintenance of RLs } \\
\text { infrastructure }\end{array}$ \\
\hline $\begin{array}{l}\text { National and } \\
\text { special } \\
\text { bibliographies }\end{array}$ & $\begin{array}{l}\text { Quality targets for } \\
\text { cultural offers: } \\
\text { guests }\end{array}$ & $\begin{array}{l}\text { Further education } \\
\text { plans }\end{array}$ & $\begin{array}{l}\text { Costs in relation to } \\
\text { IT }\end{array}$ \\
\hline $\begin{array}{l}\text { Production of } \\
\text { cultural events/ } \\
\text { offers }\end{array}$ & $\begin{array}{l}\text { Quality targets for } \\
\text { web mediation }\end{array}$ & Research plans & \\
\hline $\begin{array}{l}\text { Research } \\
\text { production }\end{array}$ & Research mediation & $\begin{array}{l}\text { Optimisation of the } \\
\text { hybrid library }\end{array}$ & \\
\hline
\end{tabular}


Diagram 7: $\quad$ Critical Success factors 2003

\begin{tabular}{|c|c|c|c|c|}
\hline & A: Internal & B: user/outside world & C: Development & $\begin{array}{l}\text { D: } \\
\text { Economics/runni } \\
\text { ng of library }\end{array}$ \\
\hline 1 & Collection building & Loans/e-usage & $\begin{array}{l}\text { Staff political } \\
\text { development area }\end{array}$ & IT-infrastructure \\
\hline 2 & Legal deposit & Visitors & Research & $\begin{array}{l}\text { Making internal } \\
\text { running of RL } \\
\text { more effective }\end{array}$ \\
\hline 3 & Cultural offers & $\begin{array}{l}\text { Quality targets for } \\
\text { library services }\end{array}$ & $\begin{array}{l}\text { Quality develoment } \\
\text { for cultural offers }\end{array}$ & Insourcing/incom \\
\hline 4 & $\begin{array}{l}\text { Quality targets for } \\
\text { collection building }\end{array}$ & $\begin{array}{l}\text { Quality targets for } \\
\text { cultural offers }\end{array}$ & $\mathrm{RL}$ as digital library & $\begin{array}{l}\text { Outsourcing } \\
\text { projects }\end{array}$ \\
\hline 5 & $\begin{array}{l}\text { Physical collection } \\
\text { preservation }\end{array}$ & Guidance & Digitisation & \\
\hline 6 & & $\begin{array}{l}\text { Cooperation } \\
\text { Copenhagen } \\
\text { University/RL }\end{array}$ & Retro-conversion & \\
\hline 7 & & & Building projects & \\
\hline 8 & & & $\mathrm{RL}$ as hybrid library & \\
\hline 9 & & & IT-projects & \\
\hline 10 & & & $\begin{array}{l}\text { Preservation } \\
\text { projects }\end{array}$ & \\
\hline & $\begin{array}{l}\text { All objectives are } \\
\text { updated quarterly }\end{array}$ & & & \\
\hline
\end{tabular}

Each department has its own contract and profile in balanced scorecard terms. In the department contract it is stated how the department is contributing to the fulfilment of the institution's goal for the year in question. And the department contract includes a table of critical success factors relevant for the department and the related performance indicators stating the department's concrete goal for the four quarters of the year on the selected performance indicators. In diagram 8 is shown a portion relating to document delivery from the department Main collection and Document Delivery: It can be seen that the department has planned to produce 170.150 REX orders for the whole year. The diagram also shows the level of precision, which is to be used in connection with balanced scorecard. 
Diagram 8: $\quad$ Performance indicator

\begin{tabular}{|c|c|c|c|c|c|c|c|c|}
\hline Measures & Frequency & & \begin{tabular}{|l} 
BSC \\
MODEL
\end{tabular} & ID NO. & PERIOD & REAL & TARGET & \begin{tabular}{|l|} 
MEASURE \\
ID
\end{tabular} \\
\hline & $\begin{array}{l}\text { Update } \\
\text { type }\end{array}$ & Result & MODEL & MEASUREID & PERIODID & ACTUAL & PLANNED & Units \\
\hline $\begin{array}{l}\text { REX- } \\
\text { orders }\end{array}$ & Q & 40.489 & \begin{tabular}{|l|} 
2003BSC \\
2003Q4
\end{tabular} & $3 \mathrm{KXnLb01a}$ & 200301 & 40.489 & 42.538 & Units \\
\hline $\begin{array}{l}\text { REX- } \\
\text { orders }\end{array}$ & Q & & $\begin{array}{l}\text { 2003BSC } \\
2003 \mathrm{Q} 4\end{array}$ & $3 \mathrm{KXnLb01a}$ & 200302 & 40.489 & 85.075 & units \\
\hline $\begin{array}{l}\text { REX- } \\
\text { orders }\end{array}$ & $\mathrm{Q}$ & & \begin{tabular}{|l|} 
2003BSC \\
2003Q4
\end{tabular} & $3 \mathrm{KXnLb01a}$ & 200303 & 40.489 & 127.613 & units \\
\hline \multirow[t]{2}{*}{$\begin{array}{l}\text { REX- } \\
\text { orders }\end{array}$} & Q & & \begin{tabular}{|l|} 
2003BSC \\
2003Q4 \\
\end{tabular} & $3 \mathrm{KXnLb01a}$ & 200304 & 40.489 & 170.150 & units \\
\hline & & & & & & & & units \\
\hline $\begin{array}{l}\text { Gul-e- } \\
\text { orders }\end{array}$ & Q & 6.619 & \begin{tabular}{|l|} 
2003BSC \\
2003Q4 \\
\end{tabular} & $3 \mathrm{KXnLb01a}$ & 200301 & 6.619 & 6.150 & units \\
\hline $\begin{array}{l}\text { Gul-e- } \\
\text { orders }\end{array}$ & Q & & \begin{tabular}{|l} 
2003BSC \\
2003Q4
\end{tabular} & $3 \mathrm{KXnLb01a}$ & 200302 & 6.619 & 12.300 & units \\
\hline $\begin{array}{l}\text { Gul-e- } \\
\text { orders }\end{array}$ & Q & & \begin{tabular}{|l|} 
2003BSC \\
2003Q4 \\
\end{tabular} & $3 \mathrm{KXnLb01a}$ & 200303 & 6.619 & 18.450 & units \\
\hline \multirow[t]{2}{*}{$\begin{array}{l}\text { Gul-e- } \\
\text { orders }\end{array}$} & Q & & \begin{tabular}{|l|} 
2003BSC \\
2003Q4
\end{tabular} & $3 \mathrm{KXnLb01a}$ & 200304 & 6.619 & 24.600 & units \\
\hline & & & & & & & & units \\
\hline $\begin{array}{l}\text { Manual } \\
\text { orders } \\
\text { (received } \\
\text { in stack) }\end{array}$ & Q & 5.380 & $\begin{array}{l}\text { 2003BSC } \\
\text { 2003Q4 }\end{array}$ & $3 \mathrm{KXnLb01a}$ & 200301 & 5.380 & 3.075 & units \\
\hline $\begin{array}{l}\text { Manual } \\
\text { orders } \\
\text { (received } \\
\text { in stack) }\end{array}$ & Q & & $\begin{array}{l}\text { 2003BSC } \\
\text { 2003Q4 }\end{array}$ & $3 \mathrm{KXnLb01a}$ & 200302 & 5.380 & 6.150 & units \\
\hline $\begin{array}{l}\text { Manual } \\
\text { orders } \\
\text { (received } \\
\text { in stack) }\end{array}$ & Q & & $\begin{array}{l}\text { 2003BSC } \\
\text { 2003Q4 }\end{array}$ & $3 \mathrm{KXnLb01a}$ & 200303 & 5.380 & 9.225 & units \\
\hline $\begin{array}{l}\text { Manual } \\
\text { orders } \\
\text { (received } \\
\text { in stack) }\end{array}$ & Q & & $\begin{array}{l}\text { 2003BSC } \\
2003 Q 4\end{array}$ & $3 \mathrm{KXnLb01a}$ & 200304 & 5.380 & 12.300 & units \\
\hline
\end{tabular}




\section{ORGANISATIONAL CHANGE AND BALANCED SCORECARD}

Early in 2002 it was decided that we had to re-organise the main department structure of the library in order to be able to run it within the narrow budget frames set up for 2003. In analysing the departmental structure we used the balanced scorecard to set up a matrix where the one dimension contained all the critical success factors for each of the four perspectives and the other dimension contained the new departments. As can be seen from diagram 9 this was used to identify where each department was going to contribute. This scheme gives an independent definition of the products of the library and a systematic way to delimit the area of responsibility of the new departments.

Diagram 9: $\quad 2003$ Departments, Objectives and Measures

\begin{tabular}{|c|c|c|c|c|c|c|c|c|c|c|c|c|c|c|c|c|c|}
\hline & & & & & $\begin{array}{l}\mathbf{P} \\
\mathbf{l} \\
\mathrm{i} \\
\mathrm{g} \\
\mathrm{t} \\
\\
\mathrm{B}\end{array}$ & $\begin{array}{l}\text { Spec. } \\
\text { saml'er } \\
\text { C }\end{array}$ & $\begin{array}{l}\mathbf{P} \\
\mathrm{u} \\
\mathrm{b} \\
\mathrm{l} . \\
\\
\\
\mathrm{H}\end{array}$ & $\begin{array}{l}\mathbf{K} \\
\mathbf{U} \\
\mathbf{L} \\
\mathbf{T}\end{array}$ & $\begin{array}{l}\text { D } \\
\text { D } \\
\text { A } \\
\\
\text { J }\end{array}$ & $\begin{array}{l}\mathbf{H} \\
\mathbf{D} \\
\mathbf{A}\end{array}$ & $\begin{array}{l}\text { B } \\
\text { I } \\
\text { A } \\
\\
\text { L }\end{array}$ & $\begin{array}{l}\mathbf{B} \\
\mathbf{E} \\
\mathbf{V} \\
\\
\\
\mathbf{M}\end{array}$ & $\begin{array}{l}\mathbf{E} \\
\mathbf{D} \\
\mathbf{B} \\
\\
\\
\\
\mathbf{N}\end{array}$ & $\begin{array}{l}\mathbf{F} \\
\mathbf{O} \\
\mathbf{A} \\
\\
\\
\\
\mathbf{O}\end{array}$ & $\begin{array}{l}\mathbf{A} \\
\mathbf{D} \\
\mathbf{M} \\
\\
\\
\mathbf{P}\end{array}$ & $\begin{array}{l}\mathbf{T} \\
\mathbf{e} \\
\mathrm{k} \\
\mathrm{n} \\
\mathrm{i} \\
\mathrm{k} \\
\\
\\
\mathbf{Q}\end{array}$ & $\begin{array}{l}\text { M } \\
\text { e } \\
\text { a } \\
\text { s } \\
\text { u } \\
\text { r } \\
\text { e } \\
\text { ID }\end{array}$ \\
\hline \multicolumn{18}{|c|}{$\begin{array}{l}\text { A. Internal (capacity } \\
\text { building) }\end{array}$} \\
\hline \multirow[t]{5}{*}{$\mathbf{A}$} & 1 & $\begin{array}{l}\text { Collection } \\
\text { building }\end{array}$ & & & & & & & & & & & & & & & \\
\hline & & & & $\begin{array}{l}\text { Conventional } \\
\text { (monographs) }\end{array}$ & & & & & & & $\mathrm{X}$ & & & & & & $\begin{array}{l}\text { physical } \\
\text { unit }\end{array}$ \\
\hline & & & 2 & $\begin{array}{l}\text { Conventional } \\
\text { (serial titles) }\end{array}$ & & & & & & & $X$ & & & & & & $\begin{array}{l}\text { no of } \\
\text { titles }\end{array}$ \\
\hline & & & & $\begin{array}{l}\text { Electronic } \\
\text { (monographs) }\end{array}$ & & & & & $X$ & & & & & & & & $\begin{array}{l}\text { physical } \\
\text { unit }\end{array}$ \\
\hline & & & 4 & $\begin{array}{l}\text { Electronic } \\
\text { (serial titles) }\end{array}$ & & & & & $X$ & & & & & & & & $\begin{array}{l}\text { no of } \\
\text { titles }\end{array}$ \\
\hline \multirow{2}{*}{\multicolumn{2}{|c|}{$\mathbf{A}$}} & $\begin{array}{l}\text { Legal } \\
\text { deposit }\end{array}$ & & & & & & & & & & & & & & & \\
\hline & & & 1 & $\begin{array}{l}\text { Conventional } \\
\text { (monographs) }\end{array}$ & $\mathrm{X}$ & & & & & & & & & & & & $\begin{array}{l}\text { physical } \\
\text { unit }\end{array}$ \\
\hline
\end{tabular}




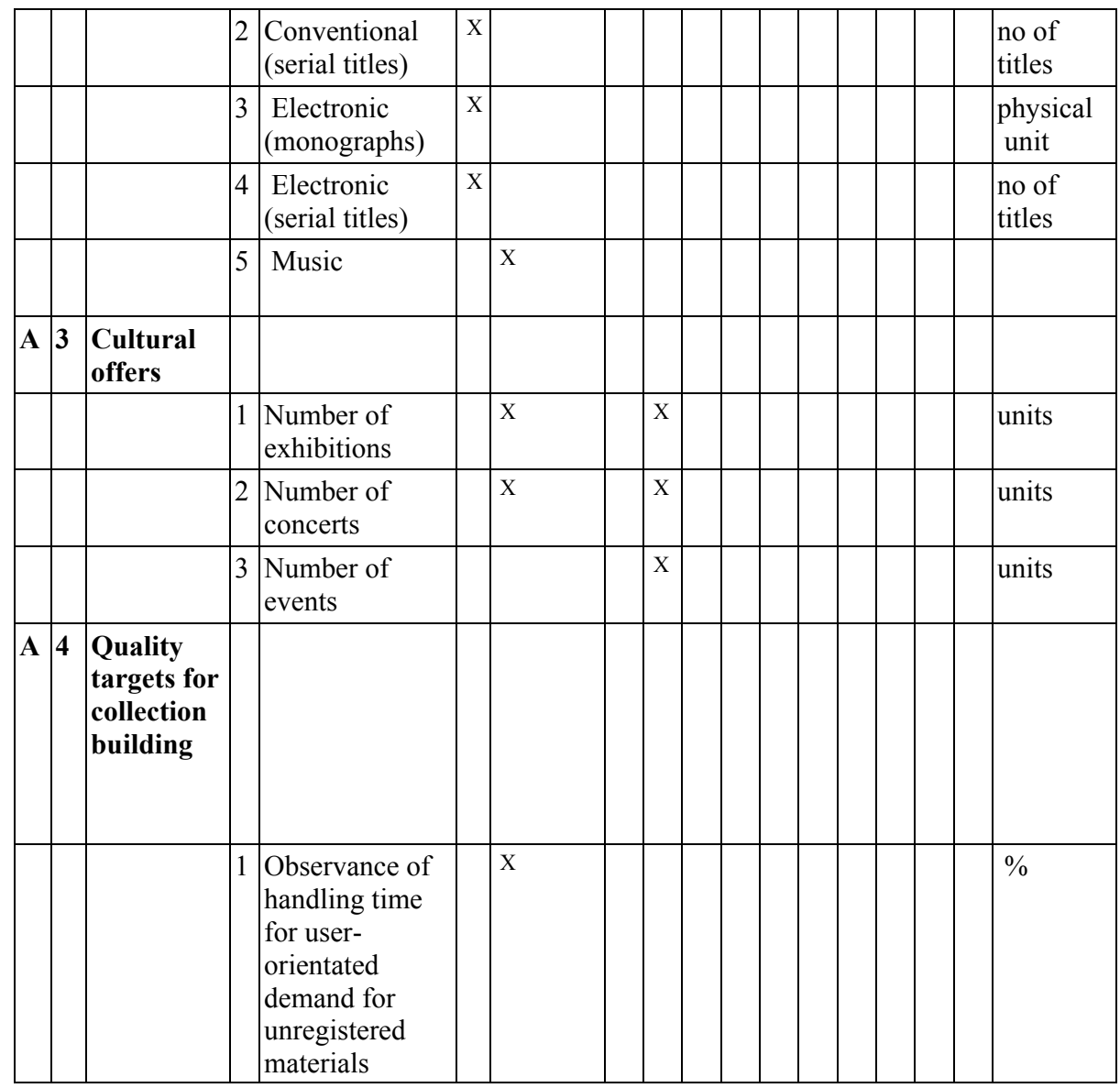

There can be made a number of observations relating to the use of the balanced scorecard

- $\quad$ Setting up and implementing a balanced scorecard for an institution constitutes a collective explicatory and clarification process, which has its own value in developing the understanding of the library and the understanding of the connection between different parts of the library.

- One of the main strategic goals was to encourage the use of the Royal Library and at the same time make it more cost effective. Diagram 10 shows the actual usage 2001 and 2002 measured in loans, request for advice and visits to service points. 
Diagram 10: $\quad$ Usage 2001 and 2002 measured in loans, request for advice and visits $\underline{\text { to service points }}$

\begin{tabular}{|l|l|l|l|}
\hline Total (in 1,000) & $\mathbf{2 0 0 0}$ & $\mathbf{2 0 0 1}$ & $\mathbf{2 0 0 3}$ \\
\hline Loans & 854 & 1.407 & 1.965 \\
\hline Requests & 113 & 97 & 79 \\
\hline Visits & 944 & 786 & 801 \\
\hline
\end{tabular}

Source: Annual statistics 2000, 2001, 2003

As can be seen we have enjoyed a high increase in lending and a reduction in the other two forms of usage.

- $\quad$ Measuring quality.

One of the important issues is measuring quality. It is a known fact that you cannot measure quality. It is also often the same people stating this who feel that they are capable of recognising quality. In a balanced scorecards' context the important job is to set up performance indicators which can be used for measuring quality. For example the quality of a good exhibition can be measured by the amount of favourable mentioning in the press. This being a performance indicator, the head of department counts the press cuts with favourable mentioning, and we then get an exact idea about the extent of this. And when the head of department reports on the exhibition measured in these terms, he also works pro-actively to get the attention of the press, so that they get mentioning in the press.

- The $100 \%$ syndrome.

Another quality discussion is registered under the $100 \%$ syndrome. This syndrome states for example that a borrower must always have his request fulfilled within the announced delivery time. This is not a practical goal, and neither is it an economic one. Instead we have set up exact quality and service norms. The goal is that the loan desk shall be able to have a $95 \%$ fulfilment of the institution's delivery deadlines as regards documents for loans. And from delivery from the stacks we have set the goal at $97 \%$ fulfilment of the institution's delivery deadlines so that there is a $2 \%$ error space on the way to the user.

This goal has been fulfilled, and it is worth stating that the actual goal realisation of $95 \%$ is $100 \%$ goal fulfilment, because we set the goal at $95 \%$. It is an important policy to set high and realistic goals so that it is possible to fulfil them, and so that resources are not wasted in reaching for the impossible. 


\section{THE HYBRID LIBRARY}

Our balanced scorecard has also been used in developing our idea about the hybrid library. The hybrid library is defined as a library, which includes conventional as well as digital collections and catalogues of the collections. The hybrid library gives a considerable augmentation of the library's complexity as regards number of tasks. And the media change from conventional to digital documents brings about alterations of the library's fundamental precondition.

We have spelled out the targets for the Royal Library as a hybrid library, and it is stated in diagram 11.

Diagram 11: $\quad$ Targets for the Royal Library as a hybrid library

\section{To extend:}

- the digital part of the library's collections

- the digital availability of collections and information

- the digital administration of the library

in order to:

- extend the users' access to relevant information

thereby:

- encourage the users to use self-service

- making the library more efficient

- reducing the use of manpower for service and administration

- reducing wear and tear on the library's original works

The Royal Library wants to make the library more digital in collections and in service forms. A hybrid indicator should therefore be able to measure the amount in which the library is becoming more digital.

As part of our analysis of the hybrid library we set up the scheme in diagram 12, stating the key indicators for conventional and electronic services. 
Diagram 12: $\quad$ Key indicators for conventional and electronic services

\begin{tabular}{|l|l|l|l|}
\hline Forms of usage & $\begin{array}{l}\text { Conventional } \\
\text { library services }\end{array}$ & $\begin{array}{l}\text { Electronic library } \\
\text { services }\end{array}$ & $\begin{array}{l}\text { Target: Increased } \\
\text { electronic user } \\
\text { service }\end{array}$ \\
\hline $\begin{array}{l}\text { Requests for } \\
\text { documents }\end{array}$ & Manual requests & Electronic requests & $\begin{array}{l}\text { Larger share of } \\
\text { electronic requests }\end{array}$ \\
\hline $\begin{array}{l}\text { Delivery of } \\
\text { documents }\end{array}$ & $\begin{array}{l}\text { Conventional } \\
\text { loans } \\
\text { Works on paper }\end{array}$ & $\begin{array}{l}\text { Electronic } \\
\text { document delivery } \\
\text { Works in e-form }\end{array}$ & $\begin{array}{l}\text { Larger share of } \\
\text { electronic document } \\
\text { delivery }\end{array}$ \\
\hline $\begin{array}{l}\text { Requests for general } \\
\text { guidance functions } \\
\text { Info-desk and } \\
\text { telephone }\end{array}$ & $\begin{array}{l}\text { User enquiries and } \\
\text { individual personal } \\
\text { guidance }\end{array}$ & $\begin{array}{l}\text { User visits on } \\
\text { www guidance } \\
\text { pages }\end{array}$ & $\begin{array}{l}\text { Fall in share of } \\
\text { personal enquiries } \\
1) \text { irt visits at service } \\
\text { points } \\
2) \text { irt visits at } \\
\text { www.kb.dk }\end{array}$ \\
\hline $\begin{array}{l}\text { Requests for } \\
\text { guidance functions } \\
\text { Centres and reading } \\
\text { rooms }\end{array}$ & $\begin{array}{l}\text { User enquiries and } \\
\text { individual personal } \\
\text { guidance }\end{array}$ & $\begin{array}{l}\text { User visits on } \\
\text { www guidance } \\
\text { pages }\end{array}$ & $\begin{array}{l}\text { Fall in share of } \\
\text { personal enquiries } \\
1) \text { irt visits at service } \\
\text { points } \\
2) \text { irt visits at } \\
\text { www.kb.dk }\end{array}$ \\
\hline $\begin{array}{l}\text { Guests in reading } \\
\text { rooms and centres }\end{array}$ & $\begin{array}{l}\text { Guests in reading } \\
\text { rooms and centres }\end{array}$ & $\begin{array}{l}\text { User visits on } \\
\text { www guidance } \\
\text { pages }\end{array}$ & $\begin{array}{l}\text { Increased number of } \\
\text { visits both on } \\
\text { www.kb.dk and in } \\
\text { reading rooms and } \\
\text { centres }\end{array}$ \\
\hline $\begin{array}{l}\text { Visits at service } \\
\text { points }\end{array}$ & $\begin{array}{l}\text { User visits at } \\
\text { service points }\end{array}$ & $\begin{array}{l}\text { User visits on } \\
\text { www guidance } \\
\text { pages }\end{array}$ & $\begin{array}{l}\text { Increase in user visits } \\
\text { on www-pages larger } \\
\text { than in visits at service } \\
\text { points }\end{array}$ \\
\hline
\end{tabular}

In the four columns are stated the general forms of usage, the conventional library service, the electronic library service and the targets of increased electronic user service respectively

On request for documents we want a larger share of electronic request, in delivery of documents we want a larger share of electronic documents delivery, and concerning requests for general guidance we want a reduction in the share of personal enquiries and then increase on our web service and so on.

As part of our analysis we have also used our indicators to spell out the causal relations of the activities going on inside the Library, see diagram 13. 
Diagram 13: $\quad$ Causal relation in a hybrid library




The left part of the diagram lists functions under capacity building, i.e. acquisition of conventional collections, retro-conversion and so on. Next is the produced capacity, REX is our on-line catalogue, E-resources is the digital collection available and the Royal Library's websites. The actual usage is expressed in K-loans, which are the conventional loans and e-loans, which are electronic loans, relating e-loans to the k-loans you get an indicator for the digital content of our document delivery. The diagram also spells out that if we are going to increase our electronic capacity, we are going to have an IT development project, and we are going to have qualified staff and so on as shown in the diagram.balanced scorecard lends precision to this analysis.

Diagram 14 shows how the Royal Library in 2002 managed to fulfil its goal for optimising the hybrid library. And it can also be seen how the balanced scorecard can be used to integrate a number of indicators into one overall indicator, the hybrid indicator.

Diagram 14: $\quad$ The hybrid indicator

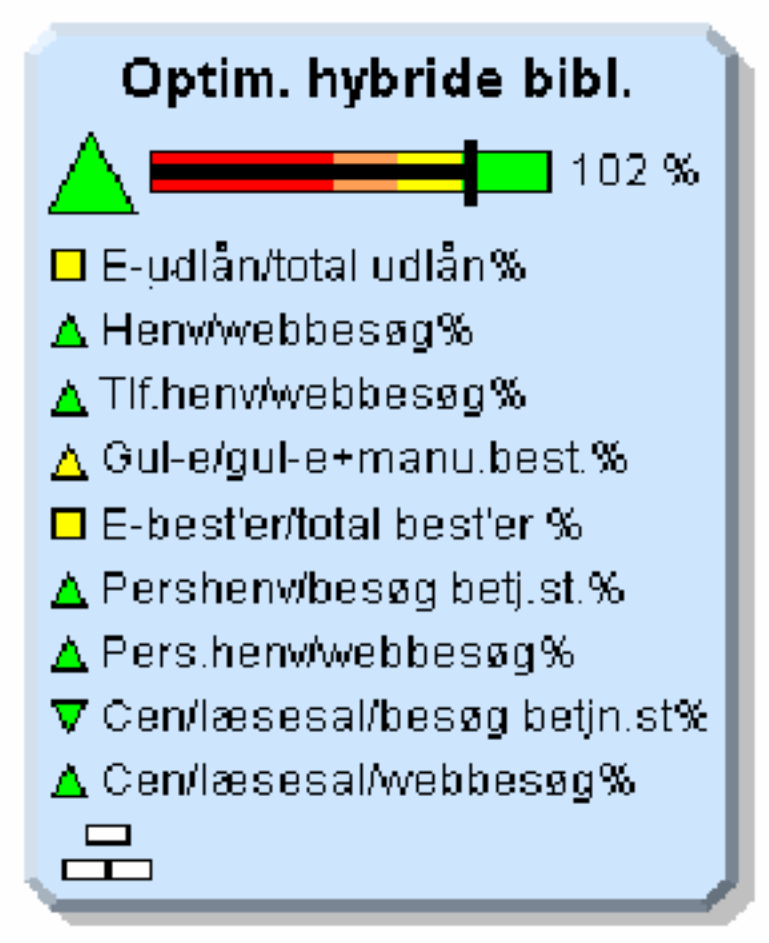


Diagram 15 shows that document delivery has changed from purely conventional document delivery in 1995 to a high proportion of electronic document delivery in 2002.

Diagram 15: $\quad$ Document delivery $1995-2002$

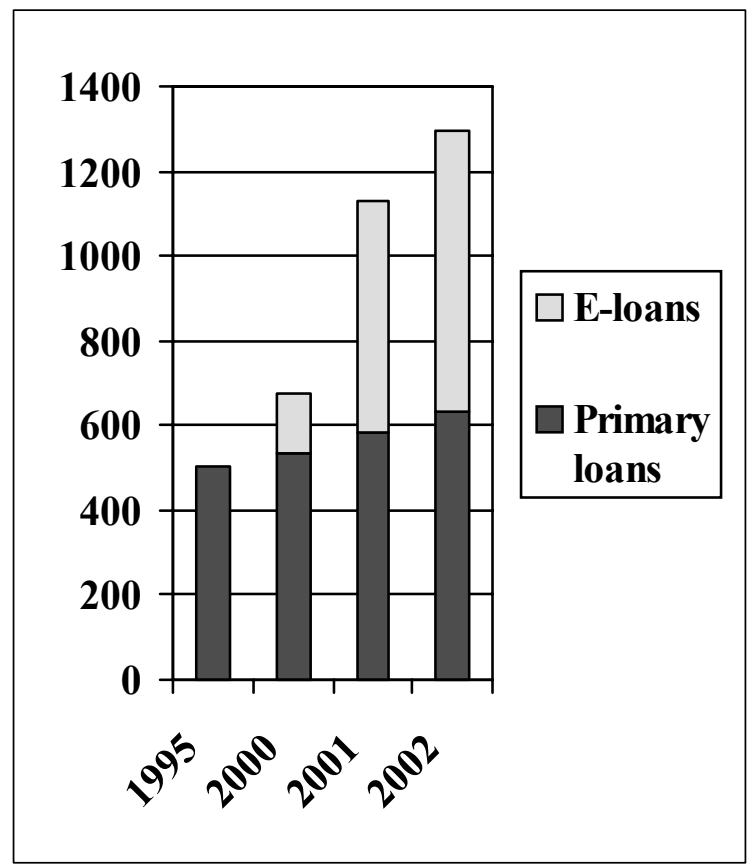

This can be expressed in a hybrid indicator for document delivery diagram 16 , where the proportion of electronic document delivery is shown. 
Diagram 16: $\quad$ Hybrid indicator for document delivery

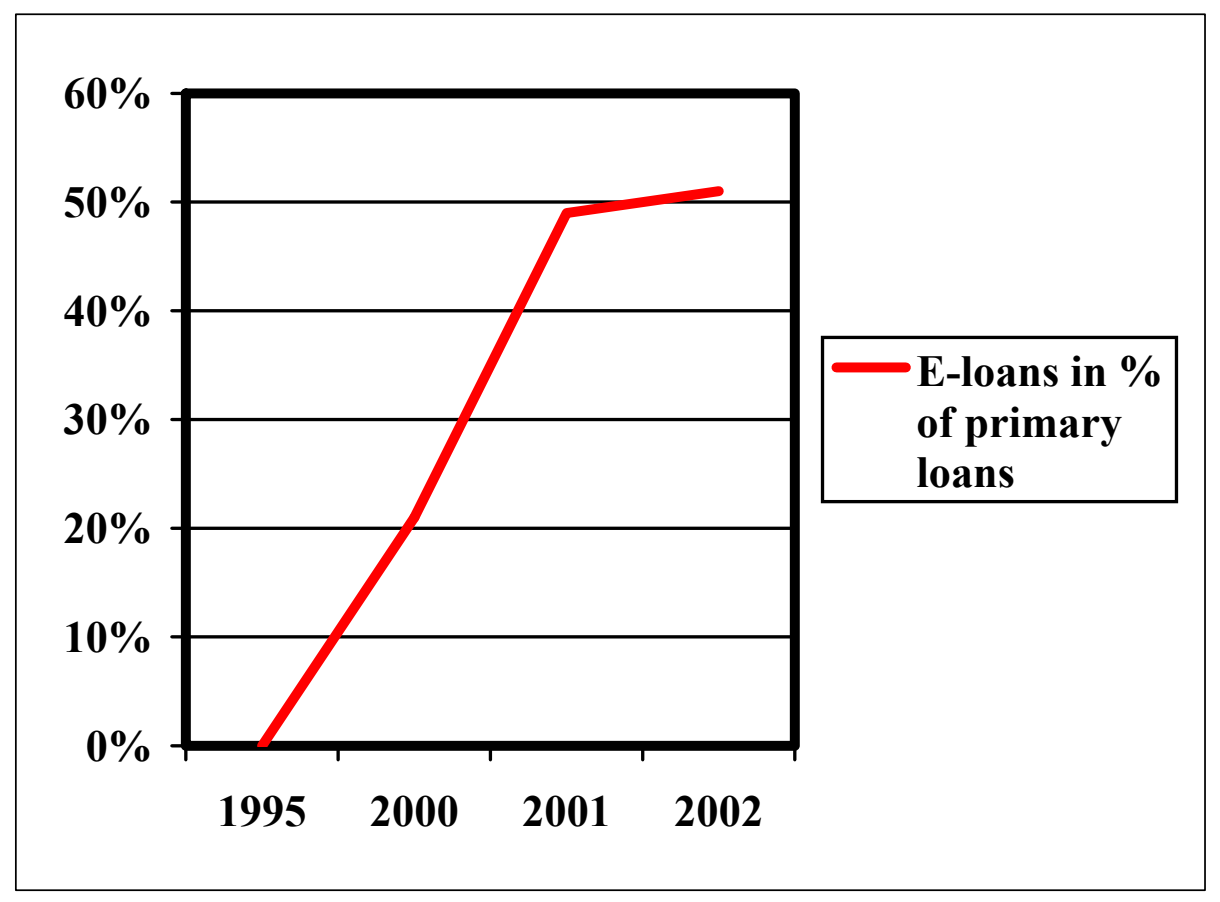

The Royal library has crossed the line of 50\%. From 2002 the Royal Library has a higher proportion of electronic document delivery than of conventional document delivery. This is a very significant change in the library's service profile. 


\section{CONCLUSIONS JUNE 2003}

There are a number of conclusions related to the use of balanced scorecard at the Royall:

- A balanced scorecard is a useful instrument for connecting the institution's visions and strategic targets and the daily running of the library.

- It requires a good deal of work and ability to focus to develop a sufficient and manageable set of success factors and key indicators.

- As an instrument for management, reporting and follow-up it gives an easy and clear overview of the relation between goals and fulfilment.

- It is a useful and clear instrument in development and estimation of services.

- It is also a useful instrument in organisational development and cause/effect analyses.

- A balanced scorecard is not just a measure for control, it is just as much a method for learning. Having precise measures of a goal, it is possible to observe if you are reaching the goal. But how can you know, whether you have succeeded, if your goal is poorly identified.

\section{WEB SITES REFERRED TO IN THE TEXT}

The Royal Library. http://www.kb.dk/index-en.htm 